\title{
EVALUASI PEMANFAATAN MEDIA AUDIO GELARIA (GERAK DAN LAGU ANAK CERIA)
}

\section{UTILIZATION EVALUATION OF GELARIA AUDIO MEDIA}

\author{
Kulsum Nur Hayati \\ Fungsional Pengembang Teknologi Pembelajaran pada BPMRP Kemendikbud \\ Jalan Sorowajan Baru 367 Banguntapan, Yogyakarta, Indonesia \\ kulsum.nur@kemdikbud.go.id
}

Diterima tanggal: 10 Oktober 2016, dikembalikan untuk direvisi tanggal: 26 Oktober 2016, disetujui tanggal 11 November 2016

\begin{abstract}
Abstrak: Penelitian ini bertujuan untuk mengevaluasi pemanfaatan media audio Gelaria dalam menstimulasi kemampuan seni dan fisik motorik anak usia dini. Penelitian ini merupakan penelitian evaluasi dengan teknik survey di 8 propinsi, yaitu: DIY, Sulawesi Barat, NTT, Jawa Barat, Bengkulu, Jawa Timur, Banten, dan Kalimantan Selatan. Teknik sampling menggunakan purposive sampling dengan jumlah sampel 24 guru dan 80 anak didik. Judul media audio Gelaria yang digunakan dalam pembelajaran yaitu "Angsa". Teknik pengumpulan data dengan observasi pemanfaatan model, kuesioner tentang pemanfaatan Gelaria untuk pendidik PAUD, dan lembar pengamatan surveyor. Analisis data dilakukan secara deskriptif untuk menafsirkan data tentang ketercapaian tujuan pengembangan model. Hasil penelitian menunjukkan: 1) siswa dapat menyanyikan lagu sesuai nada dan irama musik dengan baik (85\%); dan 2) siswa dapat melakukan gerakan sesuai lirik lagu dan irama musik dengan baik (85\%). Gerakan yang dilakukan beragam, mulai dari menggerakkan kepala sampai menggerakkan kaki. Hasil penelitian juga menunjukkan jenis-jenis gerakan yang siswa mengalami kesulitan dalam melakukannya. Berdasar hasil penelitian saran yang perlu ditindaklanjuti yaitu Gelaria perlu dikembangkan lebih lanjut dengan jenis gerakan yang lebih bervariasi dan simpel serta lagu yang mudah dihafalkan oleh anak usia dini. Gelaria perlu dikembangkan lebih lanjut agar kemampuan fisik motorik anak dapat distimulasi dengan tepat dan membantu guru yang kesulitan dalam menumbuhkembangkan fisik motorik anak.
\end{abstract}

Kata Kunci: evaluasi, seni, fisik motorik, media audio Gelaria.

Abstract: This study aimed to evaluate the use of audio media Gelaria in stimulating artistic ability and physical motor skills of young children. This study is the evaluation of the survey technique in 8 provinces of Yogyakarta, West Sulawesi, East Nusa Tenggara, West Java, Bengkulu, East Java, Banten and South Kalimantan. The sampling technique used purposive sampling with a sample of 24 teachers and 80 students. Title Gelaria audio media used in the learning of "Angsa". Data collection techniques with the use of a model observation, a questionnaire on the use Gelaria for early childhood educators, and surveyor observation sheet. The data were analyzed descriptively to interpret data on the achievement of the objectives of model development. The results showed: 1) students can sing songs to suit the tone and rhythm of the music with a good (85\%); and 2) students can perform corresponding movements song lyrics and rhythm of the music with a good (85\%). Movements performed diverse, ranging from moving the head to move the legs. The results also suggest the kinds of movements that students have difficulty in doing so. Based on the results of research that need to be followed that advice Gelaria should be developed further with more varied types of movement and is simple and easy songs memorized by younger children. Gelaria need to be developed further so that the physical capabilities of the child's motor can be stimulated with the right and help teachers develop physical motor difficulties in children.

Keywords: evaluation, art, physical motor skills,, audio media Gelaria. 


\section{PENDAHULUAN}

Keberhasilan pendidikan untuk anak usia dini dipengaruhi oleh banyak faktor, salah satunya dipengaruhi oleh peran tenaga pendidiknya. Pendidik anak usia dini tidak hanya memiliki peran dan fungsi yang sekedar mentransfer ilmu, tapi juga memiliki tugas untuk menumbuh kembangkan berbagai bidang perkembangan anak usia dini, antara lain: kognitif, bahasa, fisik motorik, seni, sosial emosional, dan nilai-nilai agama moral. Setiap bidang perkembangan anak usia dini tersebut, memerlukan stimulasi yang tepat. Stimulasi dapat dilakukan dengan berbagai teknik, di antaranya dengan pemanfaatan berbagai media pembelajaran.

Pemanfaatan Teknologi Informasi dan Komunikasi (TIK) dalam pembelajaran pada Pendidikan Anak Usia Dini (PAUD) masih sangat terbatas. Pembelajaran PAUD masih lebih banyak yang bersifat konvensional dan kegiatan pembelajarannya masih bersifat satu arah. Keterbatasan kemampuan untuk memanfaatkan media pembelajaran berbasis TIK di kalangan guru PAUD disinyalir menjadi salah satu penyebab kenyataan masih banyaknya guru PAUD yang belum memanfaatkan media tersebut dalam kegiatan pembelajaran. Kehadiran TIK dapat dimanfaatkan sebagai salah satu bentuk variasi pembelajaran yang selama ini dilakukan secara konvensional oleh sebagian besar guru PAUD. Dengan TIK diharapkan pembelajaran di PAUD lebih menarik dan menyenangkan untuk mengoptimalkan tumbuh kembang anak usia dini dalam seluruh aspek perkembangannya, baik aspek perkembangan kognitif, bahasa, seni, sosial emosional, maupun fisik motorik.

Perkembangan fisik motorik anak usia dini meliputi kemampuan motorik halus dan motorik kasar. Upaya menumbuh kembangkan fisik motorik dapat dilakukan melalui eksplorasi gerakan. Berbagai jenis gerakan bermanfaat untuk pengembangan aspek fisik motorik, mulai dari menggerakkan kepala sampai dengan menggerakkan kaki. Eksplorasi gerakan penting diajarkan dalam pembelajaran anak usia dini agar anak memiliki kemampuan gerak tubuh dengan menggunakan otot-otot besar sehingga anak memiliki koordinasi bagian tubuh dan keseimbangan tubuh yang baik. Pengembangan motorik khususnya motorik kasar pada anak usia dini berfungsi: (1) melatih kelenturan dan koordinasi otot jari dan tangan; (2) membentuk, membangun, dan memperkuat tubuh anak; dan (3) melatih ketangkasan gerak dan berpikir anak, meningkatkan perkembangan emosional dan sosial anak. Dalam menstimulasi perkembangan fisik motorik, dapat beriringan dengan menumbuh kembangan aspek seni. Stimulasi seni pada anak terkait dengan pengembangan kecerdasan musikal.

Dalam mengembangkan media pembelajaran untuk menumbuh-kembangkan seni dan fisik motorik anak, pengembang media perlu menyesuaikan dengan karakteristik anak usia dini khususnya terkait perkembangan fisik motorik dan seni.

Media audio Gelaria (Gerak dan Lagu Anak Ceria) merupakan salah satu inovasi kreatif pengembang teknologi pembelajaran dari BPMRPK Kemdikbud. Media audio Gelaria adalah model media audio pembelajaran gerak dan lagu dalam bentuk gerakan sesuai lirik lagu anak usia dini. Spesifikasi model Gelaria, yaitu: gerakan sesuai lirik lagu, program berisi lagu (musik dan vokal), tiap program berisi 3 lagu (awal, inti, akhir) dikemas secara midley, lirik lagu sesuai judul program, format file MP3, durasi 3 menit, alat pemutar: MP3, komputer, smartphone; dan sifat program sebagai suplemen. Kerangka program Gelaria yaitu: lagu pembuka (tune) program dan narasi pembuka dengan durasi 1,5 menit; gerakan yang diajarkan sesuai lirik lagu dengan durasi 3 menit; dan narasi penutup serta lagu penutup 1,5 menit.

Setelah model media audio Gelaria ini dikembangkan, selanjutnya model tersebut di lakukan bimbingan teknis untuk kemudian dimanfaatkan dalam pembelajaran. Setelah pemanfaatan Gelaria dalam pembelajaran PAUD, selanjutnya BPMRPK Kemendikbud melaksanakan evaluasi pemanfaatan Gelaria dalam pembelajaran. Penelitian ini menyajikan hasil evaluasi pemanfaatan Gelaria dalam Pembelajaran. Penelitian ini dimaksudkan untuk mengetahui apakah pembelajaran menggunakan model Gelaria dapat menumbuhkembangkan fisik motorik dan seni pada anak usia dini. Gerak dan lagu dalam media audio Gelaria diartikan sebagai melakukan gerakan 
berdasarkan lirik lagu. Pengertian tersebut perlu dipertegas mengingat dalam sejarah gerak dan lagu di dalam pendidikan anak usia dini mengalami beberapa perubahan sesuai masanya. Ada masa di mana gerak dan lagu dikaitkan dengan gerakangerakan senam (olahraga). Ada juga masa di mana gerak dan lagu dilakukan dengan menggunakan lagulagu yang sudah ada sebelumnya, sehingga sulit membedakan antara kegiatan gerak dan lagu dan menari sambil bernyanyi yang juga diajarkan di Taman Kanak-kanak.

Balai Pengembangan Media Radio Pendidikan dan Kebudayaan berdasarkan masukan dari para praktisi pendidikan PAUD berusaha mengembalikan bentuk gerak dan lagu yang sebenarnya. Gerak dan lagu yang benar adalah gerakan-gerakan yang dilakukan ansih sesuai dengan lirik lagu. Beberapa penelitian yang dilakukan di Indonesia, banyak membuktikan bahwa gerak dan lagu mempunyai peranan sangat penting dalam proses tumbuh kembangnya seorang anak. Musik memberikan keseimbangan hidup bagi anak. Bernyanyi dan bergerak adalah suatu kegiatan yang disukai anak, memberikan kepuasan, kebahagiaan sehingga mendorong anak lebih giat dan bersemangat. Dengan nyanyianpun anak menjadi mudah mempelajari sesuatu.

Berdasarkan latar belakang di atas, permasalahan yang diangkat dalam penelitian ini adalah apakah model media audio Gelaria dapat meningkatkan kemampuan fisik motorik dan seni anak?. Tujuan penelitian ini yaitu untuk mengevaluasi pemanfaatan media audio Gelaria dalam pembelajaran PAUD. Sedangkan manfaat penelitian ini yaitu untuk mendeskripsikan kemampuan bernyanyi dan melakukan berbagai gerakan sesuai lirik lagu melalui pemanfaatan media audio pembelajaran Gelaria (Gerak dan Lagu Anak Ceria) dalam pembelajaran di PAUD.

Pengembangan media audio Gelaria ini diharapkan bermanfaat bagi pendidik PAUD yang mengalami kesulitan dalam memberikan stimulasi perkembangan fisik motorik dan seni pada anak. Dengan memanfaatkan media audio Gelaria ini diharapkan pembelajaran lebih variatif dan menyenangkan. Oleh karena itu, pengembang media ini hendaknya memperluas penyebaran media ini sehingga akan memperkaya media pembelajaran yang dimiliki oleh lembaga PAUD di Indonesia sehingga kualitas pembelajaran di PAUD akan meningkat, sedangkan bagi peneliti lain dapat menjadi bahan acuan atau rujukan dalam melalukan penbelitian yang relevan.

\section{KAJIAN LITERATUR}

Perkembangan pada anak usia dini meliputi perkembangan bahasa, kognitif, sosial emosional, seni, dan fisik motorik (baik motorik kasar maupun halus). Masa usia dini merupakan masa pertumbuhan paling hebat. Pada masa ini, ketrampilan dan kemampuan anak dapat dieksplorasi sesuai tahap perkembangannya. Pada saat anak mencapai usia 4-6 tahun, terdapat ciri yang sangat berbeda jika dibandingkan usia sebelumnya. Ciri yang berbeda tersebut di antaranya adalah proporsi tubuh yaitu berat dan panjang badan, kemampuan berkomunikasi, serta ketrampilan yang dimiliki.

Pada usia 4-6 tahun, otot-otot tubuh anak telah berkembang sehingga memungkinkan mereka melakukan berbagai jenis ketrampilan olah tubuh. Gerakan-gerakan yang dilakukan anak lebih terkendali dan terorganisasi (Sujiono, 2008) karena pada masa ini, ketrampilan motorik kasar dan halus sangat pesat perkembangannya. Secara umum, anak pada usia ini sangat aktif, mereka sudah memiliki penguasaan tubuh yang cukup baik. Oleh karena itu, pada masa ini, waktu yang ideal untuk mempelajari ketrampilan motorik kasar sebab: (1) tubuh anak lebih lentur; (2) anak belum memiliki banyak ketrampilan sehingga untuk mempelajari ketrampilan baru lebih mudah; (3) anak lebih berani mencoba; (4) anak-anak menyukai pengulangan sehingga mereka senang mengulangi aktivitas tersebut sehingga otot menjadi terlatih dan anak dapat melakukan secara efektif; dan (5) anak memiliki waktu lebih banyak untuk mempelajari ketrampilan motorik (Sujiono, 2008).

Mengajarkan ketrampilan fisik motorik pada anak lebih tepat diajarkan ketika anak sudah bisa mencontoh gerakan-gerakan orang dewasa di sekitarnya. Perubahan yang terjadi pada anak dapat 
diamati, biasanya terjadi secara teratur dan relatif dapat diprediksi. Sebagai contoh, sebelum anak bisa berjalan, pertama-tama anak belajar duduk tegak, merangkak, berdiri dengan bantuan, dan kemudian berdiri dengan bantuan. Proses tersebut merupakan tahapan yang teratur dan dapat diprediksi. Mengajarkan keterampilan fisik motorik bukan pekerjaan yang mudah, terkadang ada orangtua yang sangat khawatir terhadap anaknya sehingga memberikan perlindungan secara berlebihan. Perlindungan berlebihan ini disebabkan oleh kurangnya pengetahuan orangtua atau pengasuhnya, sehingga anak tidak memiliki waktu yang leluasa untuk bergerak. Misalnya anak terlalu sering digendong, naik turun tempat tidur tidak boleh. Hal ini justru akan menghambat perkembangan motorik kasar anak (Sundari \& Rumini: 2004).

Perkembangan fisik motorik anak usia dini meliputi kemampuan motorik halus dan motorik kasar. Perkembangan motorik kasar yang dimaksud mencakup: kemampuan menggerakkan tubuh secara terkoordinasi, lentur, seimbang, lincah, lokomotor, non lokomotor, dan mengikuti aturan (Kemdikbud, 2014). Ketrampilan lokomotor meliputi gerak tubuh berpindah tempat, seperti: berjalan, berlari, melompat, berguling, dan sebagainya. Ketrampilan lokomotor (Hildayani, 2008) membantu membangun kesadaran anak akan tubuhnya. Kesadaran ini disebut kesadaran persepsi motorik, meliputi: kesadaran akan tubuh sendiri, ruang, waktu, konsep arah, visual, dan pendengaran. Kesadaran ini terlihat dari upaya anak dalam melakukan peniruan gerakan. Sedangkan ketrampilan non lokomotor (Hildayani, 2008) yaitu ketrampilan dalam menggerakkan anggota tubuh dengan posisi tubuh diam di tempat. Contohnya yaitu: mengangkat, membungkuk, memutar, bergoyang, dan sebagainya. Ketrampilan ini sering dikaitkan dengan keseimbangan atau kestabilan tubuh, yaitu gerakan yang membutuhkan keseimbangan pada taraf tertentu. Selain keterampilan lokomotor dan non lokomotor, yang tidak kalah pentingnya adalah kemampuan manipulatif (Saputra, 2005) yang dapat dikembangkan ketika anak dapat menggunakan tangan untuk melakukan berbagai gerakan, seperti: melempar, memukul, menendang, dan menangkap.

Upaya untuk menumbuhkembangkan fisik motorik dapat dilakukan melalui eksplorasi gerakan. Berbagai jenis gerakan bermanfaat untuk pengembangan aspek fisik motorik, mulai dari menggerakkan kepala sampai dengan menggerakkan kaki. Eksplorasi gerakan penting diajarkan dalam pembelajaran anak usia dini agar anak memiliki kemampuan gerak tubuh dengan menggunakan otot-otot besar sehingga anak memiliki koordinasi bagian tubuh dan keseimbangan tubuh yang baik. Pengembangan motorik khususnya motorik kasar pada anak usia dini berfungsi: melatih kelenturan dan koordinasi otot jari dan tangan, membentuk, membangun, dan memperkuat tubuh anak, melatih ketangkasan gerak dan berpikir anak, meningkatkan perkembangan emosional dan sosial anak.

Perkembangan motorik adalah perkembangan pengendalian gerakan jasmaniah melalui kegiatan pusat syaraf, urat syaraf, dan otot yang terkoordinasi (Hurlock, 2006). Sedangkan ketrampilan motorik kasar adalah ketrampilan yang meliputi aktivitas otot besar, seperti menggerakkan lengan dan berjalan. Ketrampilan motorik kasar dapat berkembang dan memerlukan kontrol posisi tubuh, seperti sebelum seorang anak dapat berjalan, ia harus mampu menyeimbangkan diri di atas satu kaki (Santrock, 2007). Berdasarkan pengertian di atas, gerakan motorik kasar merupakan gerakan tubuh yang menggunakan otot-otot besar atau sebagian besar atau seluruh anggota tubuh yang dipengaruhi oleh kematangan anak itu sendiri.

Ada 5 prinsip perkembangan motorik kasar, yaitu: (1) perkembangan motorik kasar bergantung pada kematangan otot dan syaraf; (2) berlangsung secara terus menerus; (3) memiliki pola yang diramalkan; (4) reflek primitif akan hilang dan digantikan gerakan yang disadari; dan (5) urutan perkembangan pada anak sama tetapi kecepatannya berbeda (Hurlock, 2006). Berdasarkan pendapat tersebut, untuk menstimulasi kemampuan motorik anak perlu memperhatikan 5 prinsip perkembangan motorik kasar.

Pendidik anak usia dini dalam memberikan stimulasi perkembangan anak usia dini juga perlu 
memperhatikan perkembangan pada aspek seni. Stimulasi seni pada anak terkait dengan pengembangan kecerdasan musikal. Ada 10 ciri kecerdasan musikal pada anak, yaitu: (1) senang memainkan alat musik; (2) senantiasa ingat irama pada suatu melodi; (3) berprestasi baik dalam bidang seni musik di sekolah; (4) senang belajar jika ada iringan musik; (5) mengoleksi berbagai lagu dalam buku, CD, atau kaset; (6) senang menyanyi, baik untuk sendiri maupun orang lain; (7) mudah mengikuti irama lagu/musik; (8) memiliki suara yang bagus untuk bernyanyi; (9) peka terhadap suara-suara di lingkungan sekitarnya; dan (10) memberikan reaksi yang kuat terhadap berbagai jenis musik (Jamaris, 2015). Ciri-ciri kecerdasan musikal ini penting untuk diketahui pendidik PAUD agar dapat mengetahui sejak dini apa potensi dasar yang dimiliki anak didik sehingga dapat memberikan stimulasi yang tepat.

Beberapa penelitian tentang upaya peningkatan kemampuan motorik kasar dijadikan sebagai acuan dalam penelitian ini. Penelitian yang dilakukan di RA Muslimat NU Sukosari Bandongan Magelang pada 10 siswa menyimpulkan bahwa pembelajaran senam fantasi meningkatkan kemampuan motorik kasar siswa yang ditunjukkan sebesar 5\% dengan pemberian pembelajaran senam anak sholeh; dan peningkatan sebesar $35 \%$ dengan pemberian pembelajaran senam sehat gembira (Utami, 2014) . Penelitian lain menunjukkan bahwa melalui permainan melempar dan menangkap bola dapat meningkatkan kemampuan motorik kasar anak usia dini di PAUD Al Ikhlas Kepahiang Bengkulu (Erlinda, 2014). Berdasarkan penelitian tersebut dapat diketahui beberapa teknik yang dapat dilakukan untuk menumbuhkembangkan kemampuan motorik anak usia dini. Namun penelitian tersebut belum memanfaatkan media pembelajaran untuk menambah kemenarikan dan ketertarikan siswa dalam pembelajaran. Penelitian yang dilakukan oleh fungsional pengembang teknologi pembelajaran di BPMRPK Kemdikbud menunjukkan bahwa pemanfaatan media audio untuk PAUD dapat menstimulasi karakter anak usia dini (Nurhayati, 2012). Berdasarkan penelitian tersebut dapat diketahui bahwa pemanfaatan media audio PAUD
(MAPAUD) dengan format cerita dapat menumbuhkan karakter rasa ingin tahu dengan indikator anak mampu mengajukan pertanyaan dan menceritakan kembali isi cerita yang telah didengarkan. Oleh karena itu, pemanfaatan media pembelajaran diperlukan untuk lebih memotivasi dan lebih menambah kemenarikan pelaksanaan pembelajaran yang bertujuan mengembangkan kemampuan fisik motorik dan seni.

Berdasarkan penelitian yang telah dilakukan dapat diketahui bahwa stimulasi perkembangan fisik motorik dan seni pada anak dapat dilakukan dengan berbagai gerakan yang diajarkan dan disertai dengan iringan musik yang sesuai dengan gerakan yang diajarkan. Oleh karena itu, dibutuhkan sebuah media audio yang inovatif dan kreatif yang dapat membantu guru dalam menstimulasi perkembangan fisik motorik dan seni pada anak usia dini. Media audio Gelaria merupakan sebuah karya inovatif sekaligus kreatif, memadukan instruksi-instruksi gerakan dengan musik dan nyanyian yang disukai oleh anak-anak. Dengan demikian, melalui pemanfaatan media audio Gelaria, perkembangan fisik motorik dan seni anak menjadi lebih optimal.

\section{METODE PENELITIAN}

Penelitian ini termasuk jenis penelitian evaluasi, yaitu evaluasi pemanfaatan media pembelajaran. Penelitian dilakukan dengan menggunakan metode survai untuk mengetahui ketercapaian tujuan pemanfaatan media audio Gelaria, yaitu mengetahui kemampuan bernyanyi dan melakukan berbagai gerakan melalui pengenalan lagu dan gerak sesuai lirik lagu anak dalam program Gelaria. Survei dilakukan di 8 (delapan) lokasi di propinsi DI Yogyakarta, Banten, Jawa Barat, Jawa Timur, Bengkulu, Kalimantan Selatan, Sulawesi Barat, dan Nusa Tenggara Timur. Penelitian dilakukan selama tiga bulan yaitu bulan September sampai dengan Nopember 2015.

Pengumpulan data pemanfaatan media audio Gelaria menggunakan tiga instrumen, yaitu: lembar pengamatan siswa, angket untuk pendidik PAUD, dan lembar pengamatan pendidik PAUD. Populasi dalam penelitian ini adalah anak didik dan pendidik PAUD 
dari 8 provinsi di Indonesia. Teknik sampling menggunakan purposive sampling yang berjumlah 24 pendidik dan 80 anak didik PAUD yang berasal dari 8 propinsi.

Media audio Gelaria yang digunakan dalam kegiatan pembelajaran di PAUD berjudul "Angsa". Judul lagu, lirik lagu, dan stimulasi gerakan yang diajarkan seperti pada Tabel 1 berikut.

Tabel 1: Lagu dan Stimulasi Gerakan yang Diajarkan pada Gelaria "Angsa"

Judul lagu Lirik Lagu Deskripsi Gerakan

\begin{tabular}{|c|c|c|}
\hline \multicolumn{3}{|c|}{ Bait ke-1 } \\
\hline "Angsa" & $\begin{array}{l}\text { Beginilah jalannya, } \\
\text { beginilah jalannya, } \\
\text { Jalan si Angsa }\end{array}$ & $\begin{array}{l}\text { Kedua tangan di belakang } \\
\text { pinggul (telapak tangan } \\
\text { menghadap keluar), berjalan } \\
\text { megal-megol. }\end{array}$ \\
\hline & & $\begin{array}{l}\text { Berjalan ke samping kanan } \\
\text { sambil megal-megol. }\end{array}$ \\
\hline & $\begin{array}{l}\text { Megal megol ke } \\
\text { kiri }\end{array}$ & $\begin{array}{l}\text { Berjalan ke samping kiri } \\
\text { sambil megal megol. }\end{array}$ \\
\hline & Berputar-putar & $\begin{array}{l}\text { Berjalan memutar badan } \\
\text { sambil megal megol. }\end{array}$ \\
\hline & $\begin{array}{l}\text { Leher mengangguk- } \\
\text { angguk, leher } \\
\text { mengangguk- } \\
\text { angguk }\end{array}$ & $\begin{array}{l}\text { Berjalan kedepan, } \\
\text { menjulurkan leher, sambil } \\
\text { mengangguk-anggukkan } \\
\text { kepala. }\end{array}$ \\
\hline & Geleng kepala & $\begin{array}{l}\text { Berdiri tegak, kedua tangan } \\
\text { di belakang pinggul (telapak } \\
\text { tangan menghadap keluar), } \\
\text { menggeleng kepala }\end{array}$ \\
\hline & $\begin{array}{l}\text { Kepalanya } \\
\text { menyelam, kepala- } \\
\text { nya menyelam, } \\
\text { timbul tenggelam }\end{array}$ & $\begin{array}{l}\text { Berjalan berputar, sambil } \\
\text { menundukkan kepala, } \\
\text { kemudian mendorong dagu } \\
\text { ke depan }\end{array}$ \\
\hline & $\begin{array}{l}\text { Angsa lucu } \\
\text { berenang- } \\
\text { renang }\end{array}$ & $\begin{array}{l}\text { Berdiri tegak, menggerakan } \\
\text { pinggul, kedua tangan lurus } \\
\text { kebelakang (telapak tangan } \\
\text { berhadapan) digetarkan }\end{array}$ \\
\hline & $\begin{array}{l}\text { Sayap putih } \\
\text { dikibas-kibaskan }\end{array}$ & $\begin{array}{l}\text { Jalan di tempat, tepuk } \\
\text { tangan di belakang pinggul }\end{array}$ \\
\hline & $\begin{array}{l}\text { Liuk kanan, liuk } \\
\text { ke kiri }\end{array}$ & $\begin{array}{l}\text { Kedua tangan lurus } \\
\text { dibelakang pinggul telapak } \\
\text { tangan berhadapan, badan } \\
\text { diliukkan ke kanan dan ke kiri }\end{array}$ \\
\hline & $\begin{array}{l}\text { Lari kencang } \\
\text { mencari makan }\end{array}$ & $\begin{array}{l}\text { Kedua tangan lurus di } \\
\text { belakang pinggul telapak } \\
\text { tangan berhadapan, lari } \\
\text { kedepan }\end{array}$ \\
\hline
\end{tabular}

\begin{tabular}{|c|c|c|}
\hline "Angsa" & & Bait ke-2 \\
\hline & $\begin{array}{l}\text { Ayo kawan semua } \\
\text { rentang tangan } \\
\text { kedua tangan di } \\
\text { pinggang }\end{array}$ & $\begin{array}{l}\text { Jalan ditempat, kedua } \\
\text { tangan diangkat didepan } \\
\text { dada, kedua telapak tangan } \\
\text { menghadap ke atas } \\
\text { (gerakan mengajak). } \\
\text { Kedua tangan direntangkan } \\
\text { lurus kesamping. Kedua } \\
\text { tangan di pinggang }\end{array}$ \\
\hline & $\begin{array}{l}\text { Kaki jalan berjingkat } \\
\text { kaki jalan berjingkat } \\
\text { badan membungkuk }\end{array}$ & $\begin{array}{l}\text { Kaki jalan berjingkat maju, } \\
\text { sambil membungkukkan } \\
\text { badan }\end{array}$ \\
\hline & $\begin{array}{l}\text { Mari kita tirukan } \\
\text { gerak angsa berjalan } \\
\text { putar kekanan }\end{array}$ & $\begin{array}{l}\text { Jalan ditempat, kedua } \\
\text { tangan diangkat di depan } \\
\text { dada, kedua telapak } \\
\text { tangan menghadap ke atas } \\
\text { (gerakan mengajak). } \\
\text { Megal megol putar badan } \\
\text { kekanan }\end{array}$ \\
\hline & \multirow[t]{2}{*}{$\begin{array}{l}\text { Tangan dibuka } \\
\text { lebar dimiringkan } \\
\text { ke kanan lalu } \\
\text { mengeram }\end{array}$} & $\begin{array}{l}\text { Kedua tangan direntangkan } \\
\text { kesamping } \\
\text { Kedua tangan direntangkan, } \\
\text { tubuh dimiringkan ke kanan } \\
\text { (tangan kanan lebih rendah } \\
\text { dari tangan kiri) }\end{array}$ \\
\hline & & $\begin{array}{l}\text { Kaki jongkok, kedua tangan } \\
\text { didepan dada, telapak } \\
\text { tangan kanan ditempelkan } \\
\text { pada punggung tangan kiri. }\end{array}$ \\
\hline & $\begin{array}{l}\text { Angsa lucu } \\
\text { berenang-renang }\end{array}$ & $\begin{array}{l}\text { Berdiri tegak, menggerakkan } \\
\text { pinggul, kedua tangan lurus } \\
\text { ke belakang (telapak tangan } \\
\text { berhadapan) digetarkan. }\end{array}$ \\
\hline & $\begin{array}{l}\text { Sayap putih dikibas- } \\
\text { kibaskan }\end{array}$ & $\begin{array}{l}\text { Jalan ditempat, kedua } \\
\text { tangan (tepuk) di belakang } \\
\text { pinggul }\end{array}$ \\
\hline & $\begin{array}{l}\text { Liuk kanan, liuk } \\
\text { kekiri }\end{array}$ & $\begin{array}{l}\text { Kedua tangan lurus di } \\
\text { belakang pinggul telapak } \\
\text { tangan berhadapan, } \\
\text { badan diliukkan ke kanan } \\
\text { dan ke kiri. }\end{array}$ \\
\hline & $\begin{array}{l}\text { Lari kencang } \\
\text { mencari makan }\end{array}$ & $\begin{array}{l}\text { Kedua tangan lurus di } \\
\text { belakang pinggul telapak } \\
\text { tangan berhadapan, lari } \\
\text { ke depan }\end{array}$ \\
\hline
\end{tabular}


Tabel 1 di atas mendeskripsikan judul lagu disertai lirik lagu per baris dan gerakan apa yang dilakukan ketika lagu dalam program tersebut dinyanyikan. Pengamatan dilakukan terhadap unjuk kerja (performance) peserta didik PAUD dalam pembelajaran yang memanfaatkan media audio Gelaria, yaitu dalam menyanyikan lagu dan melakukan gerakan yang distimulasikan.

Instrumen penelitian berbentuk lembar pengamatan unjuk kerja anak dalam pembelajaran seperti pada Tabel 2. Ada 2 kemampuan yang menjadi fokus pengamatan, yaitu kemampuan anak dalam menyanyikan lagu sesuai nada dan irama serta kemampuan anak dalam melakukan gerakan sesuai lirik lagu. Pilihan jawaban kategorial sesuai skala Lickert yaitu "belum berkembang" (nilai 1), sudah berkembang (nilai 2), berkembang sesuai harapan (nilai 3), dan berkembang sangat baik (nilai 4). Pengamatan pembelajaran menggunakan Gelaria dilakukan oleh surveyor; sedangkan kuesioner pendidik PAUD untuk memperoleh data tentang pemanfaatan Gelaria. Adapun Kriteria pencapaian yang menjadi acuan dalam penelitian ini, yaitu: jika pencapaian indikator kurang dari $40 \%$ masuk dalam kriteria kurang, sedangkan jika sudah mencapai 40\% sampai dengan $75 \%$ masuk dalam kriteria cukup, dan jika lebih dari $75 \%$ masuk ke dalam kriteria dapat menyanyikan lagu dan melakukan gerakan dengan baik.

Tabel 2: Lembar Pengamatan

UNJUK KERJA ANAK

DALAM PEMBELAJARAN GERAK DAN LAGU ANAK CERIA (GELARIA)

\begin{tabular}{|c|c|c|c|}
\hline \multirow{4}{*}{ NO } & \multirow{4}{*}{$\begin{array}{l}\text { NAMA } \\
\text { ANAK }\end{array}$} & \multirow{2}{*}{\multicolumn{2}{|c|}{$\frac{\text { Indikator/Kriteria Penilaian }}{\text { UNJUK KERJA }}$}} \\
\hline & & & \\
\hline & & $\begin{array}{l}\text { Menyanyikan } \\
\text { lagu sesuai } \\
\text { nada dan } \\
\text { irama. }\end{array}$ & $\begin{array}{l}\text { Melakukan } \\
\text { gerakan } \\
\text { sesuai dengan } \\
\text { lirik lagu. }\end{array}$ \\
\hline & & $\begin{array}{llll}1 & 2 & 3 & 4 \\
\end{array}$ & $\begin{array}{llll}1 & 2 & 3 & 4 \\
\end{array}$ \\
\hline \multicolumn{4}{|l|}{1} \\
\hline \multicolumn{4}{|l|}{2} \\
\hline
\end{tabular}

\author{
Keterangan: \\ Tuliskan nama di kolom nama anak dan tanda cek (") \\ di kolom indikator. \\ $1=$ Belum Berkembang , \\ 2=Sudah Berkembang , \\ 3= Berkembang Sesuai Harapan, \\ 4=Berkembang Sangat Baik
}

\section{HASIL DAN PEMBAHASAN}

Gerakan yang diajarkan pada anak usia pra sekolah berkaitan dengan waktu, beban, ruang, dan alur. Terkait dengan waktu, maksudnya adalah cepat atau lambatnya gerakan yang dilakukan. Misalnya: gerakan yang dilakukan oleh seluruh tubuh atau sebagian tubuh dengan kecepatan yang berbeda. Mulai dari gerakan cepat sampai lambat atau sebaliknya. Gerakan tersebut juga dapat dipercepat atau diperlambat serta dapat berirama. Contohnya: gerakan lari ditempat dari pelan sampai cepat. Sedangkan terkait beban, maksudnya bentuk gerakan tersebut berat, ringan, atau sedang. Misalnya: mengangkat tangan termasuk gerakan ringan, megal-megol termasuk gerakan sedang, dan melompat termasuk gerakan yang berat. Terkait dengan ruang, maksudnya gerakan tersebut membutuhkan ruang dalam pelaksanaannya. Misalnya: gerakan maju satu langkah, gerakan memutar, atau melompat dalam ketinggian tertentu. Yang terakhir terkait alur, yaitu gerakan merupakan suatu kesatuan yang mempunyai alur yang indah, meliputi gerakan seluruh tubuh, gerakan berbagai tubuh atau yang berkaitan dengan orang atau menggunakan obyek lainnya (Mini, 2007).

Gerakan yang dilakukan anak mengkombinasikan berbagai unsur tersebut. Oleh karena itu, dalam mengembangkan program media pembelajaran yang mengajarkan berbagai gerakan, adanya tema dalam program tersebut sangatlah penting. Dalam mengajarkan gerakan kepada anak berupa gerakan apa saja dan bagaimana caranya harus disesuaikan dengan kebutuhan anak dan karakteristik anak. Gerakan-gerakan untuk menstimulasi motorik kasar pada anak harus dilatihkan pada anak sampai anak benar-benar menguasai. Caranya yaitu dengan memberikan contoh terlebih dahulu dan kemudian 
anak menirukan, dilakukan secara berulang-ulang (Sujiono, 2007). Prinsip pengulangan pada pendidikan anak usia dini ini sangat penting. Penelitian yang dilakukan Jan Muller menunjukkan bahwa program intervensi yang hanya diberikan satu bulan sekali dengan waktu 60 menit belum dapat meningkatkan kemampuan motorik anak (Muller, dkk, 2013).

Selain perkembangan fisik motorik anak, perkembangan seni juga tidak kalah pentingnya. Salah satu cara untuk menumbuhkan kreativitas dan potensi anak yaitu dengan memberikan pengalaman seni pada anak. Pengalaman seni tersebut dapat berupa menari (dance), bermain musik (music), dan bermain drama (performing art) (Sujiono, 2007). Pengalaman seni tersebut akan menstimulasi indera anak, sehingga anak menjadi ekspresif, kreatif, dan imajinatif. Stimulasi seni untuk anak akan mengembangkan berbagai potensi pada anak, antara lain: kemampuan mengekspresikan ide dan perasaan anak tentang lingkungan sekitarnya, meningkatkan kepercayaan diri, menjadikan anak kreatif dan memiliki banyak gagasan, mampu membuat keputusan tentang apa yang mereka inginkan, dan mampu memberikan tanggapan yang berbeda dari anak yang lain.

Secara umum melalui seni, anak akan dapat menyatakan perasaan dan gagasannya, meningkatkan koordinasi mata dan tangan, mengembangkan ketrampilan otot kecil, belajar tentang warna, ukuran, bentuk, serta dapat mengembangkan kreativitas dengan cara mengeksplorasi dan menggunakan alat dan bahanbahan seni. Kemampuan seni anak akan berkembang dengan baik jika kemampuan bahasa anak juga berkembang dengan baik. Karena dengan bahasa inilah anak-anak dapat memahami berbagai perintah sehingga anak dapat melakukan berbagai gerakan sesuai perintah. Penelitian Wang, dkk. menunjukkan bahwa kemampuan komunikasi awal anak berhubungan erat dengan kemampuan motorik awal anak dengan korelasi sebesar 0,70 (Wang, dkk, 2012). Pengalaman seni, terkait seni musik merupakan faktor yang penting karena musik dapat menjadi mediator untuk emosi anak dan kemampuan berinteraksinya (Vist, 2011).

Mengkolaborasikan stimulasi pada dua bidang pengembangan ini akan menguntungkan anak. Perkembangan fisik motorik dapat tercapai dengan baik dengan cara yang menyenangkan karena dilakukan bersama-sama dengan pengembangan seni pada anak. Anak akan merasa senang karena melakukan berbagai aktivitas atau gerakan dengan iringan musik, bahkan dengan menyanyikan lagulagu gembira. Gerakan yang dilakukan sesuai dengan lirik lagu yang dinyanyikannya, gerakannya pun berirama sesuai irama yang disajikan dalam program.

Model media audio gerak dan lagu anak ceria (Gelaria) ini dikembangkan dengan maksud untuk menumbuhkembangkan kemampuan motorik kasar dan seni anak usia dini. Gelaria dikembangkan dengan tema-tema tertentu dan gerakan-gerakan yang diajarkan disesuaikan dengan kebutuhan dan karakteristik anak usia 4-6 tahun.

Setiap program yang telah dikembangkan memiliki karakteristik berbeda dalam menstimulasi jiwa seni dan fisik motorik anak berupa berbagai lagu anak dan jenis-jenis gerakan tertentu. Dalam penelitian ini, ada dua indikator yang diamati yaitu anak dapat menyanyikan lagu sesuai nada dan irama musik (aspek seni) serta anak dapat melakukan gerakan sesuai lirik lagu dan irama musik dalam kegiatan pembelajaran (aspek fisik motorik) dengan memanfaatkan media audio Gelaria "Angsa".

Dalam memanfaatkan program Gelaria, ada tiga langkah yang dilakukan guru, yaitu sebelum pemanfaatan, selama, dan sesudah pemanfaatan. Berdasarkan hasil pengamatan surveyor dari BPMRP Kemendikbud, dapatlah dikemukakan bahwa: (1) sebelum pemanfaatan program, guru menyiapkan program dengan cara meng-copy program, kemudian mempelajari tujuan, lagu, syair dan gerakan yang diajarkan sesuai dengan petunjuk pemanfaatan. Selanjutnya, guru membuat jadwal pembelajaran dan skenario pembelajaran dengan memanfaatkan Gelaria, serta menjelaskan kepada anak agar anak lebih bersemangat dalam melakukan gerak dan lagu; (2) selama pemanfaatan program, guru mengawali dengan memberikan contoh gerakan, kemudian memotivasi anak agar bisa mengikuti gerakan sesuai 
lirik, dan mengarahkan anak yang belum mampu mengikuti gerakan; dan (3) sesudah pemanfaatan program, guru memberikan apresiasi berupa pujian kepada anak yang sudah dapat mengikuti gerakan dan lagu serta memberikan semangat kepada anak yang belum bisa mengikuti gerakan dan lagu. Pada bagian akhir pembelajaran, guru memberikan penilaian perkembangan anak.

Hasil observasi dalam kegiatan pembelajaran dengan memanfaatkan media audio Gelaria dengan judul "Angsa" seperti pada Gambar 1 menunjukkan $85 \%$ anak dapat menyanyikan lagu sesuai nada dan irama musik serta $85 \%$ anak dapat melakukan gerakan sesuai lirik lagu dan irama musik, lihat Gambar 1.

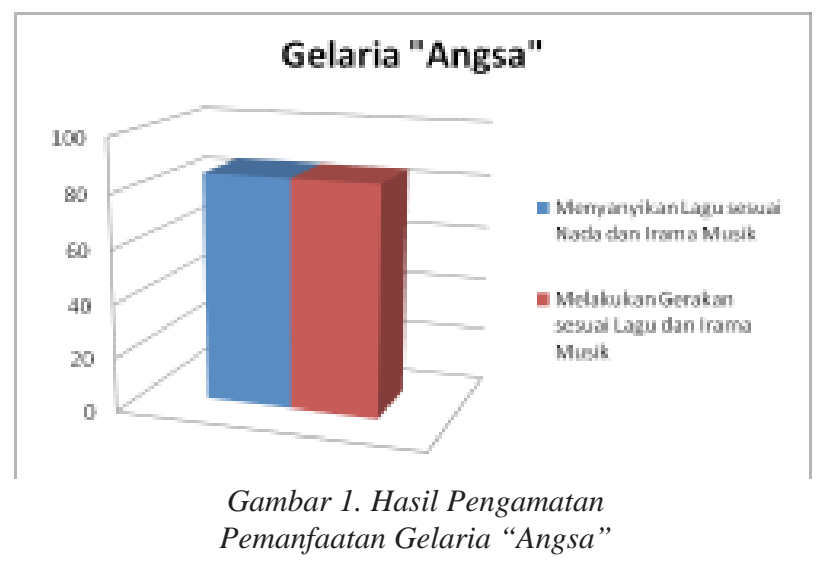

Hasil ini menunjukkan bahwa anak dapat menyanyikan lagu sesuai nada dan irama musik dengan cukup baik serta anak dapat melakukan gerakan sesuai lirik lagu dan irama musik dengan cukup baik. Lagu yang dinyanyikan berjudul "Angsa" dengan lirik lagu pada bait pertama: "beginilah jalannya, beginilah jalannya, jalan si angsa", sedangkan gerakan yang dilakukan yaitu kedua tangan diletakkan di belakang pinggul dengan telapak tangan menghadap ke luar dan berjalan megal-megol sampai dengan gerakan terakhir bait pertama, yaitu kembali berdiri tegak dengan rapi. Pada bait pertama tersebut, lagu dapat dinyanyikan dan gerakan dapat dilakukan dengan baik.

Selanjutnya, bait kedua, lirik lagu yang dinyanyikan yaitu: "ayo kawan semua rentang tangan kedua tangan di pinggang", sedangkan gerakan yang dilakukan jalan di tempat kemudian kedua tangan diangkat di depan dada, kedua telapak tangan menghadap ke atas (gerakan mengajak), kedua tangan direntangkan lurus ke samping, kedua tangan di pinggang, sampai dengan gerakan terakhir bait pertama yaitu: "kedua tangan diluruskan ke belakang pinggul dengan telapak tangan berhadapan kemudian lari ke depan". Pada bait kedua tersebut, lagu dapat dinyanyikan dan gerakan dapat dilakukan dengan baik.

Berdasarkan kriteria yang menjadi acuan, dapat disimpulkan bahwa pencapaian indikator yang diharapkan masuk ke dalam rentang antara 60\% sampai dengan $85 \%$ yang berarti bahwa ketercapaian indikator anak dapat menyanyikan lagu sesuai nada dan irama dan anak dapat melakukan gerakan sesuai lirik lagu dan irama musik dalam kriteria cukup baik dan baik. Berdasar hasil pengamatan di lapangan, hal ini terjadi karena lagu yang diajarkan membutuhkan waktu lama untuk menghafalkannya dan beberapa gerakan yang distimulasikan cukup sulit dilakukan oleh anak usia dini. Para pendidik PAUD menyarankan agar pengembangan Gelaria lebih lanjut dengan menyajikan lagu yang lebih pendek sehingga mudah diingat dan gerakan yang lebih sederhana sehingga mudah dilakukan oleh anak usia dini.

Penelitian ini juga memiliki keterbatasan, di antaranya: (1) membutuhkan waktu yang cukup lama untuk mengajarkan berbagai gerakan dan nyanyian serta mensingkronkan gerakan yang dilakukan dengan nyanyian serta musik dalam media audio Gelaria; (2) pengamatan tidak sepenuhnya dilakukan oleh peneliti, sehingga kemungkinan subyektivitas guru dalam memberikan justifikasi nilai cukup tinggi; dan (3) instrumen yang dikembangkan belum spesifik pada jenis-jenis gerakan seperti yang ada dalam standar isi. Oleh karena itu, penelitian lanjutan masih diperlukan untuk mengetahui secara mendalam terkait perkembangan fisik motorik dan seni secara lebih spesifik dan menyeluruh. 


\section{SIMPULAN DAN SARAN \\ Simpulan}

Berdasar hasil penelitian dapat disimpulkan bahwa pemanfaatan media audio Gelaria dalam pembelajaran dapat menstimulasi kemampuan seni dan fisik motorik anak usia dini. Stimulasi pada aspek seni melalui pengenalan lagu anak dan menumbuhkembangkan fisik motorik anak melalui gerak sesuai lirik lagu anak. Terbukti berdasarkan hasil pengamatan dalam kegiatan pembelajaran dengan memanfaatkan media audio Gelaria dengan judul "Angsa" menunjukkan 85\% anak dapat menyanyikan lagu sesuai nada (stimulasi seni) dan irama musik serta 85\% anak dapat melakukan gerakan sesuai lirik lagu dan irama musik (stimulasi fisik motorik).

\section{Saran}

Berdasar hasil penelitian dapat diketahui bahwa tingkat pencapaian kompetensi yang diharapkan masuk dalam kriteria baik. Disarankan untuk pengembangan program lebih lanjut, media audio juga dapat digunakan untuk menstimulasi aspek perkembangan anak usia dini yang lain.

Pengembangan media audio Gelaria ini diharapkan bermanfaat bagi pendidik PAUD yang mengalami kesulitan dalam memberikan stimulasi perkembangan fisik motorik dan seni pada anak. Dengan memanfaatkan media audio Gelaria ini diharapkan pembelajaran lebih variatif dan menyenangkan. Oleh karena itu, pengembang media ini hendaknya memperluas penyebarannya media ini sehingga akan memperkaya media pembelajaran yang dimiliki lembaga PAUD di Indonesia sehingga kualitas pembelajaran di PAUD akan meningkat. Sedangkan bagi peneliti lain, disarankan agar dapat melakukan penelitian lanjutan untuk menyempurnakan kekurangan/keterbatasan penelitian ini sehingga akan dapat diperoleh hasil yang lebih mendalam yang dapat dimanfaatkan praktisi PAUD dalam mengembangkan pembelajaran.

\section{PUSTAKA ACUAN}

Erlinda, Esti. 2014. Pengembangan Motorik Kasar Anak Usia Dini melalui Permainan Melempar dan Menangkap Bola. Skripsi. Bengkulu: Universitas Bengkulu.

Hildayani, R. 2008. Psikologi Perkembangan Anak. Jakarta: Universitas Terbuka.

Hurlock, Elizabeth, B. 2006. Psikologi Perkembangan. Jakarta: Erlangga.

Jamaris, Martini. 2006. Perkembangan dan Pengembangan Anak Usia Taman Kanak-kanak. Jakarta: Grasindo.

Kemdikbud. 2014. Permendikbud No 137 tahun 2014 tentang Standar Nasional Pendidikan Anak Usia Dini. Jakarta: Kemdikbud.

Mini, Rose, dkk. 2007. Panduan Mengenal dan Mengasah Kecerdasan Majemuk Anak. Jakarta: Indocom Prima.

Muller, Jan, dkk. 2015. Motor training of sixty minutes one per week improves motor ability in children with congenital heart disease and retarded motor development: a pilot study. Cardiology in the Young, 23, 717-721. Cambridge Universitr press.

Nurhayati, Kulsum. 2012. Implementasi pendidikan karakter melalui pemanfaatan media audio PAUD. Proceeding Seminar Nasional UNY: Implementasi Pendidikan Karakter dalam membangun Bangsa. Yogyakarta: IKA UNY Press.

Utami, Nur. 2014. Upaya Meningkatkan Kemampuan Motorik Kasar Berbasis Soft Skill melalui Pembelajaran Senam Fantasi pada Siswa Kelompok A RA Muslimat NU Magelang. Skripsi. Yogyakarta: UIN Sunan Kalijaga.

Santrock, John W. 2007. Perkembangan Anak. Jakarta: Erlangga.

Santrock, John W. 2002. Perkembangan Masa Hidup. Jakarta: Erlangga.

Saputra, Y. Rudianto. 2005. Pembelajaran Kooperatif untuk meningkatkan ketrampilan anak TK. Jakarta: Dikti.

Sujiono, Bambang. 2008. Metode Pengembangan Fisik. Jakarta: Universitas Terbuka.

Sundari, S., Rumini, S. 2004. Perkembangan Anak Remaja. Jakarta: Rinneka Cipta.

Vist, Torill. 2011. Music experience in early childhood: potential for emotion Knowledge?. IJEC. 43: 277-290. Norway: University of Stavanger. 
Wang, MV., dkk. 2012. Co-occuring development of early childhood communication and motor skills: results from a populationbased longitudinal study. Child: care, health, and development. Norway: Norwegian Institute of Public Health.

\section{UCAPAN TERIMAKASIH}

Terima kasih penulis ucapkan kepada:

Bapak Drs. Aristo Rahadi, M.Pd. yang senantiasa memberikan support agar kerja yang dilakukan dapat dituliskan menjadi hasil yang bermakna dan bermanfaat bagi dunia pendidikan.

Bapak Drs. Bambang Warsita, M.Pd. yang telah membimbing penulisan jurnal ini dengan sabar dan selalu memotivasi agar selalu bersemangat sebagai pengembang teknologi pembelajaran. 


\section{INDEK PENULIS}

\section{JURNAL TEKNODIK VOLUME 20 NOMOR 2, TAHUN 2016}

\section{A}

Ai Sri Nurhayati: Mengintegrasikan Tik Ke Dalam Pembelajaran Berbasis Pendekatan Saintifik Sesuai Kurikulum 2013. 20 (1) 029-046.

Arie Kurniawan dan Sudirman Siahaan: Kontribusi Diklat Online Terhadap Calon Pejabat Fungsional Pengembang Teknologi Pembelajaran. 20 (2) 123-131.

\section{B}

Bambang Warsita: Evaluasi Bahan Belajar Diklat Online Calon Pejabat Fungsional Pengembang Teknologi Pembelajaran. 20 (1) 059-072.

D

Djoko Rahardjo, Sumardjo, Djuara P. Lubis dan Sri Harijati: Perilaku Akses Internet Mahasiswa Pendidikan Tinggi Jarak Jauh Di Surakarta. 20 (1) 001-012.

\section{$\mathbf{F}$}

Faiza Indriastuti: Pengembangan Model Media Audio Pembelajaran untuk Meningkatkan Kemampuan Menyimak Anak Usia Dini. 20 (1) 073-084.

H

Herwina Bahar, Imam Mujtaba Dan Ismah: Penerapan Model Pembelajaran Tematik Berbasis Asmaul Husna untuk Meningkatkan Nilai-Nilai Religius. 20 (1) 047-058.

I

Ika Kurniawati: Evaluasi Pemanfaatan TVEdukasi Di 10 Kabupaten/Kota Tahun 2014. 20 (1) 013-028.

Ismah dan Sarah Afifah: Perbandingan Tingkat Pemahaman Konsep Matematika Siswa Melalui Media Interaktif Mischief dan Konvensional. 20 (2) 143-156.

Isyani: Media Gambar Yang Diproyeksikan Untuk Meningkatkan Keterampilan Menulis Puisi Pada Siswa Kelas 3 SD Banyuripan. 20 (2) 157-172.

K

Kulsum Nur Hayati: Evaluasi Pemanfaatan Media Audio Gelaria (Gerak Dan Lagu Anak Ceria). 20 (2) $173-182$.

$\mathrm{N}$

Nurita Putranti: Penggunaan Learning Together untuk Meningkatkan Aktivitas Siswa Pada Pembelajaran Microsoft Excel. 20 (2) 097-109.

$\mathbf{R}$

Rogers Pakpahan: Peranan Teknologi Informasi dan Komunikasi dalam Pengembangan Bank Soal Daerah. 20 (2) 111-121.

$\mathrm{S}$

Suparti dan Mariana Susanti: Analisis Kebutuhan Media Audio Cerita Pendidikan Karakter untuk Anak Usia Dini. 20 (2) 133-142.

Suparti: Evaluasi Model Media Audio "Permata Nusantara" untuk Pembelajaran Anak Usia Dini (PAUD) 20. (1) 085-096. 